Goals is published. The committee requests that CLS members respond with detailed criticisms and suggestions, addressed to the committee chairman. These responses will guide committee discussions at Midwinter 1975. A final report is scheduled for the Annual Conference in 1975.

\section{DRAFT STATEMENT OF CLS GOALS}

The goals of CLS shall be:

a. To provide a forum for discussion of problems concerning undergraduate library service primarily. These are problems which are either unique to the college library or, where more generalized, are of immediate and pressing concern to the college library.

b. In providing this forum, to make certain that the major concerns of all types of college library receive attention, particularly those which exist in relative geographical and professional isolation from major academic centers.

c. To arrange programs, meetings and other activities which will encourage direct membership participation.

The committee suggests that programs and activities centering around themes such as the following would make a useful beginning toward realization of goals such as the above:

The effectiveness of present "standards" or "guidelines" for the maintenance of adequate levels of service in the college library. The extent to which "standards" make a differ- ence in problem solving in the college library.

Regional cooperatives and the college library, including the concept of community use of the college library, emphasizing "best practice," management problems, fiscal implications, public relations, and similar considerations.

Data retrieval in the college library with consideration of the potential for joint use or sharing of terminals on a local or regional basis among cooperating college libraries.

The place of the nonprint media in the college library: the "learning resources center" and the college library.

Library instruction for the undergraduate, its place in the teaching-learning process and the contribution of the professional staff of the college library in the provision of this instruction.

The enlargement of graduate instruction, continuing education programs, and service to the community programs on the college campus and their impact on college library services.

Continuing education for the college library staff. The potential contribution of consortia, library schools, and other agencies in this area.

CLS members are urged to send written reactions to the foregoing in care of the committee chairman at the following address: Charles L. Higgins, Director of Learning Resources, Nazareth College of Rochester, 4245 East Avenue, Rochester, NY 14610.

\title{
Bylaws of the
}

\section{College Libraries Section of ACRL}

Approved by the membership of the ACRL College Libraries Section, on July 9, 1974.

\section{Article I. Name}

The name of this organization is the College Libraries Section of the Association of College and Research Libraries of the American Library Association.

\section{Article II. Object}

The object of the Section shall be to advance college librarianship, college library service, and the development of college libraries.

\section{Article III. Membership}

Any member of the Association of College and Research Libraries may elect membership in this Section.

$$
\text { Article IV. Officers }
$$

The officers of the Section shall be a chairman, a vice-chairman who is chairman-elect, the immediate past chairman, and a secretary. The chairman shall serve for one year. The chairman-elect shall serve for one year as vice-chairman at the expiration of which term, or upon the occurrence of an earlier vacancy in the office of chairman, he shall succeed to the office of chairman. The immediate past chairman serves for one year as an officer and the secretary serves for one year.

\section{Article V. Executive Board}

Sec. 1. Composition. The Executive Board shall consist of five members: The chairman, the secretary, the incoming chairman, the immediate past chairman, and the past secretary. The Executive Secretary of the Association of College and Research Libraries shall be an ex-officio member.

Sec. 2. Meetings. Regular meetings of the Executive Board are to be held at times and places of the annual and midwinter meetings of the 
American Library Association. Special meetings may be called at the discretion of the chairman. All regular meetings of the Board shall be open to all members of the Section.

Sec. 3. Powers and duties. The main function of the Executive Board shall be to provide direction for the Section. The board has authority over the affairs of the Section during the period between meetings of the Section, subject to review by the members at a meeting of the Section.

Sec. 4. Quorum. A majority of members constitutes a quorum at any meeting of the Executive Board.

\section{Article VI. Committees}

Sec. 1. Authorization. Committees of the Section shall be established by action of the chairman after consultation with the Executive Board.

Sec. 2. Standing Committees. Standing committees may be established to consider matters of the Section that require continuity of attention by the members. When such a committee is established its function, name, and size shall be determined. Unless otherwise approved by the Executive Board, members of standing committees shall be appointed for terms of two years and may be reappointed for a second and third but not a fourth consecutive term; in no case shall a person serve on a committee for more than six consecutive years. Appointments shall be made in such a manner as to provide continuity in membership.

Sec. 3. Special Committees. Special committees ( $\mathrm{ad} \mathrm{hoc}$ ) may be established at any time by the chairman, with the approval of the Executive Board, for the performance of a particular assignment. No such committee may be continued beyond two years without review and reapproval by the Executive Board.

Sec. 4. Appointment. The vice-chairman (chairman-elect) of the Section shall appoint committee members to fill the vacancies due to occur during his term as chairman; he may name the chairman of each committee or request the committee to elect its own chairman. Special appointments to fill vacancies on committees may be made by the chairman of the committee.

Sec. 5. Discontinuance. A committee may be dissolved by the chairman of the Section with the approval of the Executive Board.

\section{Article VII. Nominations and Elections}

Sec. 1. Nominating Committee. The vice-chairman (chairman-elect) of the Section shall appoint a Nominating Committee of at least three members, designating one of the members as committee chairman. This committee shall choose, in accordance with the time schedule set by the Executive Secretary of the Association of College and Research Libraries, a slate of two nominees for each of the offices of chairman-elect and secretary. All nominees must be members of the Section and no candidate shall be presented who has not consented in writing to his candidacy.

Sec. 2. Statement of objectives. To permit the membership of the Section to have an informational basis for voting each candidate for the office of chairman-elect shall be asked to provide a brief statement of his objectives for the Section in time for the statement to be published prior to balloting.

Sec. 3. Additional nominees. Additional nominations for inclusion on the ballot may be made by petitions signed by no fewer than twenty members of the Section and filed with the Executive Secretary of the Association of College and Research Libraries at least three months prior to the annual conference of the American Library Association. No person may be nominated who is not a member of the Section and the petition must be accompanied by the written consent of the nominee to stand for election. If the nomination is for the office of chairman-elect a statement of objectives should also be submitted.

Sec. 4. Election. Elections shall be conducted by mail ballot and the candidate receiving the largest number of votes shall be deemed elected. Results of the election shall be made public at the annual conference of the American Library Association.

\section{Article VIII. Vacancies}

When the office of the chairman or of the secretary is vacated it shall be filled by the chairman-elect or secretary-elect, and the latter shall continue in office through his original elected term. Should both the chairman and chairmanelect, or the secretary and secretary-elect, vacate their offices in the same year the Executive Board shall meet to choose a member of the Board to serve as acting chairman and/or secretary until the next regular election for the office is held.

\section{Article IX. Meetings}

The regular meeting of the Section shall be held at the time and place of the annual conference of the American Library Association. Special meetings may be called by the chairman with the approval of the Executive Board. The Section may, with the approval of the Board of Directors of the Association of College and Research Libraries, hold closed meetings or joint meetings with other sections.

\section{Article X. Amendments}

Sec. 1. Proposals. Amendments to the bylaws may be proposed by any committee of the Section or by petition signed by twenty members of the Section. Proposed amendments shall be presented in writing to the chairman.

Sec. 2. Voting. The bylaws may be amended either by a mail vote approved by two-thirds of the members voting or by a two-thirds vote of the members present and voting at any given meeting of the Section. 


\section{Your Order Deserves and Gets the Dedicated Efforts of Our Entire Staff of Professionals!}

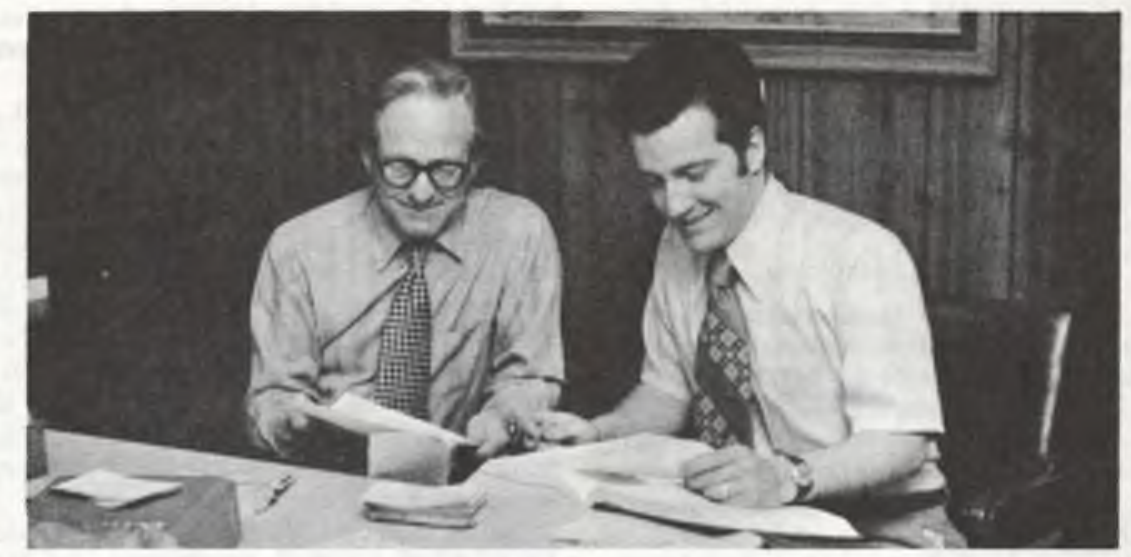

F rom President Jack Ansett and General Manager Ed Lockman down through our entire organization is a sincere desire to serve you quickly, accurately and in the way that meets your special requirements best.

W e call it "Concerned Service" because we are concerned that you get the best and most personalized service available in the wholesale book trade. Your rush orders are handled by special, separate procedures that assure you there can be no slip-up or delay in getting them completed.

Our Concerned Service assures you that the average elapsed time of delivery will be less when you order from the Book House. Surveys by several major academic libraries have confirmed this. (names on request)

B ook House will deliver any book in print including all university presses, professional and non-profit associations, Government publications, Canadian titles and ALL paperbacks from any publisher.

D iscount schedules are competitive, naturally! Isn't it time you gave Book House a trial order and found out how well Concerned Service can do the job for you!

ANY QUESTIONS? CALL 517-849-9361 COLLECT!

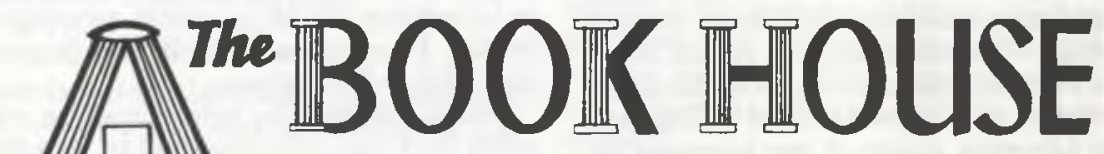

The House of Superior Library Service 208 West Chicago / Jonesville, Mich. 49250 